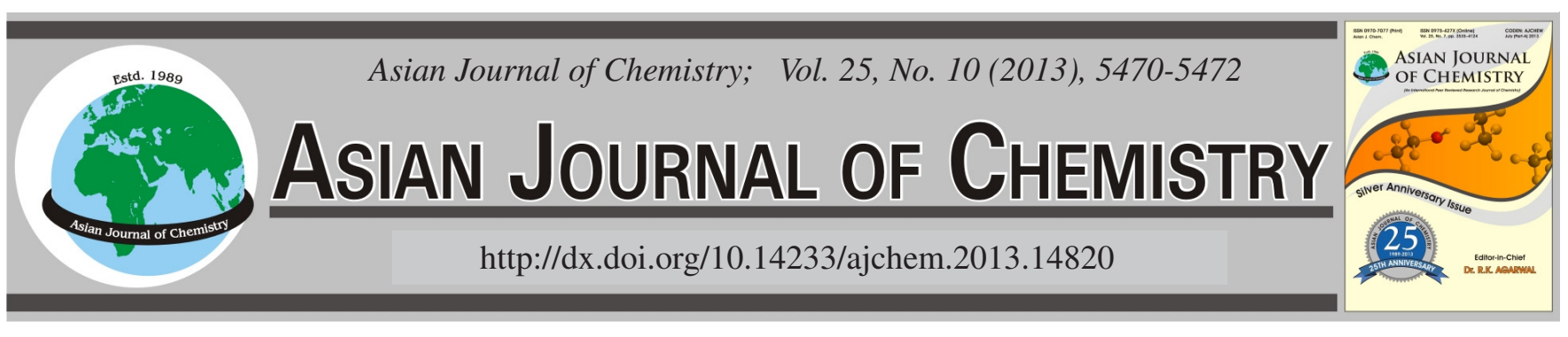

\title{
Spectrophotometric Determination of Protein with DBC-Chlorophosphonazo
}

\author{
Qing-Shuang Wang, Qing-Zhou Zhai* and Jia Luo
}

Research Center for Nanotechnology, Changchun University of Science and Technology, Changchun 130022, P.R. China

*Corresponding author: E-mail: zhaiqingzhou@163.com

(Received: 15 November 2012;

Accepted: 13 April 2013)

AJC-13232

\begin{abstract}
A new spectrophotometric method for the determination of protein has been developed using the property that bovine serum albumin and DBC-chlorophosphonazo form a compound. The maximum absorption wavelength of the compound is $606 \mathrm{~nm}$. Beer's law is obeyed over the range of $25-250 \mu \mathrm{g} / \mathrm{mL}$ of bovine serum albumin contents. The detection limit of this method is $9.52 \mu \mathrm{g} / \mathrm{mL}$. Protein content in human serum has been successfully determined.
\end{abstract}

Key Words: Protein, Spectrophotometry, DBC-Chlorophosphonazo, Bovine serum albumin, OP-100.

\section{INTRODUCTION}

Protein is the substance base of life and its existential style and action inside biological body is variable. Some are structural material of biological body, while some are functional substance. Most of the enzymes inside biological body are protein. Most parts of hormones, which promote and adjust physiological biochemical action, are also protein. Mankind must realize characteristics of various proteins and only uses beneficial function and instead protects harmful action on mankind ${ }^{1,2}$.

For the determination method of protein, Lowry method, biuret method, or Bradford method (also called Coomassie brilliant blue method) etc. are the most adopted methods, but these methods have a series of short comings, such as low sensitivity, poor linear relationship, etc., ${ }^{3,4}$. For the spectrophotometric determination of protein, great attention has been received owing to easy operation, fast speed and good repeatability and the use of it is more. Although methyl blue ${ }^{5}$, arsenazo-III ${ }^{6}$, xylenol orange-zirconium(IV) complex $^{7}$ have been applied to the spectrophotometric determination of protein, the sensitivity and selectivity are not ideal. Setting up a new method for the determination of protein still has an important theoretical and applied value. The constitutional formula of DBC-chlorophosphonazo $\left(\mathrm{C}_{22} \mathrm{H}_{13} \mathrm{Br}_{2} \mathrm{Cl}_{2} \mathrm{~N}_{4} \mathrm{O}_{11} \mathrm{PS}_{2}\right.$, DBC-CPA], is shown as Fig. 1.

The reagent has been mainly used in the spectrophotometric analysis of rare earths ${ }^{8}$. This paper found that in sulphuric acid medium and in the presence of surface active agent OP-100, DBC-chlorophosphonazo and bovine serum albumin can quickly react to form a compound. This paper studied the optimum conditions of reaction of bovine serum albumin-(DBC-CPA)-OP system, established a new method for the determination of protein contents and successfully used this method to determine the contents of protein in human serum samples.<smiles></smiles>

Fig. 1. Structural formula of DBC-chlorophosphonazo

\section{EXPERIMENTAL}

$2 \mathrm{mg} / \mathrm{mL}$ solution of bovine serum albumin (Shanghai Huishi Biochemical Reagents Co. Ltd., China):0.2 g of bovine serum albumin was dissolved in $100 \mathrm{~mL}$ of water and put into a refrigerator at $4{ }^{\circ} \mathrm{C}$ for storage. DBC-Chlorophosphonazo solution (Shanghai Changke Institute of Reagents, Jinshen Chem. Co. Ltd., China): 0.0835g of DBC-chlorophosphonazo was dissolved in $100 \mathrm{~mL}$ of water to prepare $1.0 \times 10^{-3} \mathrm{~mol} / \mathrm{L}$ of DBC-chlorophosphonazo solution. $1 \mathrm{~mol} / \mathrm{L} \mathrm{H}_{2} \mathrm{SO}_{4}$ solution and $1 \%$ OP-100 solution (v/v) were used. All the reagents were of analytical reagent and the water was deionized water. A 721 type spectrophotometer (Shanghai Spectrum Instruments Co. Ltd., China), was used for the measurement of absorbance.

$1.3 \mathrm{~mL}$ of $1.0 \times 10^{-3} \mathrm{~mol} / \mathrm{L}$ DBC-chlorophosphonazo solution, $0.6 \mathrm{~mL}$ of $1 \mathrm{~mol} / \mathrm{L} \mathrm{H}_{2} \mathrm{SO}_{4}$ solution, $0.8 \mathrm{~mL}$ of $1 \%$ (v/v) OP-100 solution and $1 \mathrm{~mL}$ of $2 \mathrm{mg} / \mathrm{mL}$ bovine serum albumin solution were put in a $10 \mathrm{~mL}$ volumetric flask, then 
the contents was diluted to the mark with water and shaken well. After $0.5 \mathrm{~h}$, the absorbance of system containing protein $\left(\mathrm{A}_{1}\right)$ and the absorbance of blank system no containing protein $\left(\mathrm{A}_{2}\right)$ was determined against water at $606 \mathrm{~nm}$ and the difference of absorbance was calculated : $\Delta \mathrm{A}=\left(\mathrm{A}_{1}-\mathrm{A}_{2}\right)$.

\section{RESULTS AND DISCUSSION}

Absorption spectra: The absorbance spectra are shown in Fig. 2. The absorption peaks of compound and reagent blank $v s$. water are at $550 \mathrm{~nm}$. The absorption peak of BSA-(DBCCPA) compound vs. reagent blank, i.e. $\mathrm{A}_{1}-\mathrm{A}_{2}$, is at $606 \mathrm{~nm}$. This work selected $606 \mathrm{~nm}$ as the determination wavelength.

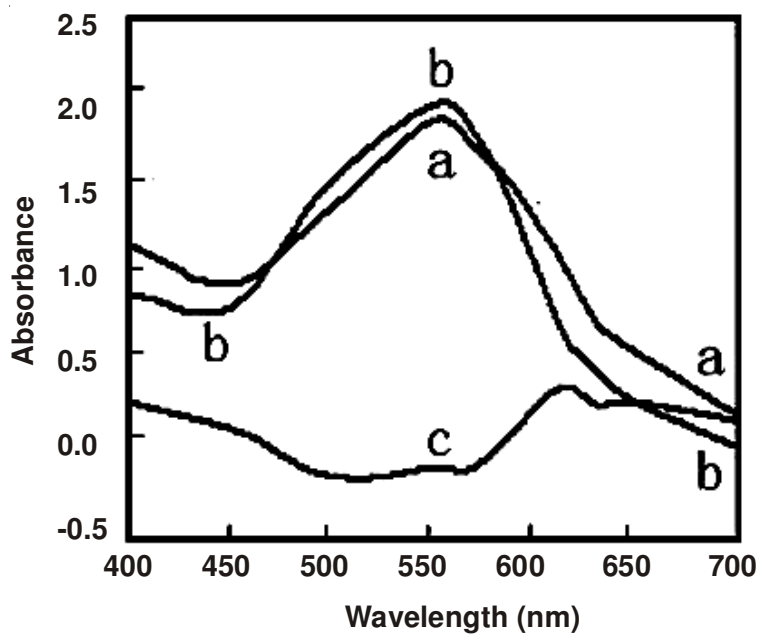

Fig. 2. Absorbance spectra: (a) BSA-(DBC-CPA)-OP vs. water, $\mathrm{A}_{1}$; (b) (DBC-CPA)-OP $v s$. water, $\mathrm{A}_{2} ;$ (c) $\Delta \mathrm{A}=\mathrm{A}_{1}-\mathrm{A}_{2} ;[\mathrm{BSA}]=2.94 \times 10^{-6}$ $\mathrm{mol} / \mathrm{L} ;[\mathrm{DBC}-\mathrm{CPA}]=1.3 \times 10^{-4} \mathrm{~mol} / \mathrm{L} ;\left[\mathrm{H}_{2} \mathrm{SO}_{4}\right]=0.06 \mathrm{~mol} / \mathrm{L} ;[\mathrm{OP}-$ $100](\mathrm{v} / \mathrm{v})=0.08 \%$

Effect of amount of sulphuric acid: The researched results show that with increasing the amount of sulphuric acid over the range of $0.2-0.6 \mathrm{~mL}$, the $\Delta \mathrm{A}$ of system increased. The systematic $\Delta \mathrm{A}$ was a maximum at $0.6 \mathrm{~mL}$. After it, with the increase of amount of sulphuric acid, the $\Delta \mathrm{A}$ decreased. In the experiment, $0.6 \mathrm{~mL}$ of $1 \mathrm{~mol} / \mathrm{L} \mathrm{H}_{2} \mathrm{SO}_{4}$ was chosen.

Effect of amount of DBC-chlorophosphonazo: The experimental results show that the absorbance gradually increased with the increase of colour reagent DBC-CPA over the range 0 to $1.2 \mathrm{~mL}$. Over the range of $1.2-1.4 \mathrm{~mL}$, the absorbance was stable and maximum. Then, with the increase of amount of colour reagent, the absorbance gradually decreased. In order to obtain the highest sensitivity, the amount of $1.0 \times 10^{-3} \mathrm{~mol} / \mathrm{L} \mathrm{DBC-CPA}$ was selected to be $1.3 \mathrm{~mL}$.

Effect of surfactant: The effects of the cationic surfactant cetyltrimethylammonium bromide, anionic surfactant sodium dodecyl sulfonic and non-ionic surface active agent Tween80 , OP-100 were studied on the reaction. The results show that cetyltrimethylammonium bromide, sodium dodecyl sulfonic, Tween- 80 reduced the sensitivity of the reaction. OP-100 could increase the sensitivity of the reaction. The experimental results of effect of OP-100 amount show that with increasing the amount of OP-100, the $\Delta \mathrm{A}$ increased in the range of $0-0.8 \mathrm{~mL}$. When $\mathrm{OP}-100$ amount was $0.8 \mathrm{~mL}$, the sensitivity of reaction was a maximum. The $\Delta \mathrm{A}$ gradually decreased when the amount was 0.8-1.6 mL. Therefore, 0.8
$\mathrm{mL}$ of $1 \%$ OP-100 solution ( $/ \mathrm{v}$ ) was chosen and at this time the sensitivity could be enhanced by $45.6 \%$.

Effect of time: The experiment found that $\Delta \mathrm{A}$ was maximum and stable when bovine serum albumin and DBC-CPA reacted at the normal atmospheric temperature after $0.5 \mathrm{~h}$. Within $2 \mathrm{~h}$, the variation of $\Delta \mathrm{A}$ was less than $5 \%$ and the compound retained stable.

Effect of co-existing ions: Under the optimum experimental conditions, the coexising ion effect experiments were made. When $1500 \mu \mathrm{g}$ of bovine serum albumin was determined in $10 \mathrm{~mL}$ of solution and the relative error was controlled within $\pm 5 \%$, the allowable amounts of co-existing ions (calculated by mass quality times) were as follows:ethylic acid, cysteine(2); $\mathrm{NO}_{2}^{-}$, phenylalanine(1); $\mathrm{S}_{2} \mathrm{O}_{7}^{2-}(0.8)$; glutamic acid, $\mathrm{Mg}^{2+}, \mathrm{Zn}^{2+}$, $\mathrm{Br}^{-}, \mathrm{I}^{-}, \mathrm{VO}_{3}^{-}, \mathrm{Mo}_{7} \mathrm{O}_{24}{ }^{6-}(0.2) ; \mathrm{Ni}^{2+}$, leucine, lysine (0.1); $\mathrm{Al}^{3+}$, $\mathrm{Mn}^{2+}, \mathrm{MnO}_{4}^{-}, \mathrm{Br}^{-},(0.02) ; \mathrm{Ag}^{+}(0.01) ; \mathrm{F}^{-}, \mathrm{BrO}_{3}^{-}, \mathrm{Cr}_{2} \mathrm{O}_{7}^{2-},(0.002)$; $\mathrm{Fe}^{3+}, \mathrm{Bi}^{3+}, \mathrm{Ca}^{2+}, \mathrm{Cu}^{2+}(0.001) ; \mathrm{Pb}^{2+}(0.005)$.

Working curve: The experimental results show that when bovine serum albumin contents was between 25 and $250 \mu \mathrm{g} /$ $\mathrm{mL}$, a good linear relationship between $\Delta \mathrm{A}$ and bovine serum albumin concentration is presented and Beer's law was obeyed. Its linear regression equation is $\Delta \mathrm{A}=0.0038 \mathrm{C}-0.0041$ (A: absorbance, $\mathrm{C}$ : concentration in $\mu \mathrm{g} / \mathrm{mL}$ ), with a correlation coefficient of $\mathrm{r}=0.9924$. From the working curve, molar absorptivity was calculated to be $\varepsilon_{606 \mathrm{~nm}}=2.46 \times 10^{5} \mathrm{~L} \cdot \mathrm{mol}^{-1} \cdot \mathrm{cm}^{-1}$. Eleven parallel determinations of $150 \mu \mathrm{g} / \mathrm{mL}$ of bovine serum albumin were made and the relative standard deviation was calculated to be $1.20 \%$. Eleven replicate determinations of blank solution were made and according to $3 \mathrm{~S} / \mathrm{K}$ method (S is the standard deviation of eleven blank experiments, $\mathrm{K}$ is the slope of working curve) the detection limit calculated was 9.52 $\mu \mathrm{g} / \mathrm{mL}$.

Determination of protein in serum sample: To validate the practicability of the method, the paper made the determination experiment of human serum sample. $0.5 \mathrm{~mL}$ of serum sample was taken and diluted to $10 \mathrm{~mL}$. $0.2 \mathrm{~mL}$ of the sample was taken for the determination of protein contents according to the standard procedure and the experiment for the rate of recovery and contrast method experiment were made (Table-1). In can be seen from the Table- 1 that the recovery of the method was $98.33-101.63 \%$, the relative standard deviation of five determinations was between 2.10-2.29\%. This method can meet the demand of general analysis. The results determined by the present method were agreement with those by arsenazoIII spectrophotometric contrast method.

TABLE-1

ANALYTICAL RESULTS OF SAMPLES

\begin{tabular}{ccccc}
\hline Sample & $\begin{array}{c}\text { Average } \\
(\mathrm{n}=5, \mathrm{mg} / \mathrm{mL})\end{array}$ & $\begin{array}{c}\text { Relative } \\
\text { standard } \\
\text { deviation }(\%)\end{array}$ & $\begin{array}{c}\text { Recovery } \\
(\%)\end{array}$ & $\begin{array}{c}\text { Contrast } \\
\text { method }^{*} \\
(\mathrm{mg} / \mathrm{mL})^{[6]}\end{array}$ \\
\hline 1 & 110.9 & 2.29 & 98.33 & 111.0 \\
2 & 105.50 & 2.10 & 101.63 & 105.1 \\
\hline *Arsenazo-III spectrophotometric method & & \\
\end{tabular}

\section{Conclusion}

A new method for the determination of protein using BSA(DBC-CPA)-(OP-100) system spectrophotometry has been put forward. At $606 \mathrm{~nm}$. Beer's law is followed over the range of 
$25-250 \mu \mathrm{g} / \mathrm{mL}$ of bovine serum albumin and the regression equation of working curve was $\Delta \mathrm{A}=0.0038 \mathrm{C}(\mathrm{C}: \mu \mathrm{g} / \mathrm{mL})$ 0.0041 . The protein contents in human serum sample have been successfully determined by this method and the results were satisfied.

\section{ACKNOWLEDGEMENTS}

The authors thank the support from the Natural Science Foundation of Jilin Province, P.R. China to this work (Project No.: 201215146, 242920, KYC-JC-XM -2012-059).

\section{REFERENCES}

1. Q.Z. Zhai, X.X. Zhang and X.T. Yang, J. Changchun Uni. Sci. Technol. (Nat. Sci. Ed.), 32, 165 (2009).

2. J.S. Wang, B.S. Liu, Y.M. Sun, J. Bai and C.R. Zhao, Chin. J. Spectrosc. Lab., 22, 599 (2005).

3. M.L. Guo and Y.M. Jiang, Prog. Biochem. Biophys., 23, 558 (1996).

4. M.M.A. Bradford, Anal. Biochem., 72, 248 (1976).

5. H.L. Chen, S.P. Liu and Z.F. Liu, Chin. J. Anal. Chem., 32, 698 (2004).

6. J.M. Li, X.X. Zhang, L.L. Fan, P. Dong and Q.Z. Zhai, Chem. Res. Appl., 17, 686 (2005).

7. G.Q. Zhan, W.X. Yu, C.T. Wei and J.J. Lu, J. Anal. Sci., 22, 309 (2006).

8. J.M. Pan, J.Z. Li, Q.Y. Zhang and G.Z. Fang, New Chromogenic Reagents and Their Application in Spectrophotometry. Beijing: Chemical Industry Press, China, p. 34 (2003). 